\title{
Response of Pulse and Oilseed Crops to Boron Application: A Review
}

\author{
Sunil Kumar ${ }^{1}$, Mamta Phogat ${ }^{2 *}$ and Manohar Lal ${ }^{3}$ \\ ${ }^{1}$ Department of Soil Science and Agricultural Chemistry, ${ }^{3}$ Department of Agronomy, College \\ of Agriculture, SKRAU, Bikaner - 334006, India \\ ${ }^{2}$ CCS Haryana Agriculture University, Hisar-125004, Haryana, India \\ *Corresponding author
}

A B S T R A C T

Keywords

Boron, Legume, Oil seeds

Article Info

Accepted:

07 February 2018

Available Online:

10 March 2018
The occurrence of micronutrient deficiencies in crops has increased markedly in recent years due to intensive cropping, soil erosion, leaching, liming of acid soils, reduced use of manures, increased purity of chemical fertilizers and use of marginal lands for crop production. Among the micronutrients, the boron plays an important role in flowering and fertilization process and hence boosting yield and quality of crop produce. Response of legume crops to boron application suggested that boron deficiency drastically reduced nodulation, growth and yield of legumes because of inadequate supply of carbohydrates to bacteria in the root nodules and insufficient conversion of starch to soluble sugars. Application of boron also markedly increases yield and quality of oil seed crops. The literature on the significance of Boron in growth as well as physiological functions of pulses and oil seed crops have been reviewed and presented.

\section{Introduction}

Boron is an essential micronutrient indispensable for the normal growth and development of plants. It plays an important role in flowering and fertilization process, boosting yield and quality of crop produce (Kanwar and Randhawa, 1974). It is recognized as one of the most commonly deficient micronutrients in soils as its deficiency has been reported in 132 crops over 80 countries (Shorrocks, 1997). The deficiency of boron in soils is a major cause of crop yield reduction in China, India, Nepal, and Bangladesh (Anantawiroon et al., 1997). In Indian, about one third of the soils are deficient in B spreading over wide area, and particularly in alluvial soils (Sakal and Singh, 1995; Singh, 2008). Its deficiency has been reported to the tune of $5-10 \%$ in soils of Punjab (Bansal et al., 2003; Singh and Nayyar, 1999). In general, deficiencies of B are prominent in soils of light texture and high $\mathrm{pH}$, and in areas of heavy rainfall, dry weather and high intensity of light. The magnitude of response of $\mathrm{B}$ application varies widely from crop to crop, varieties within a crop and on different soils for the same crop. The soils with high initial available boron produce lower yield response or no or even negative response to application. As the range between boron deficiency and toxicity is also 
very narrow, therefore, it needs to be applied cautiously (Sakal et al., 1999). Horticultural crops require more $\mathrm{B}$ than crucifers followed by the legumes and cereals the least, accordingly the response to $\mathrm{B}$ application in crops follows the order of horticultural crops $>$ crucifers > legumes > cereals (Ranade, 2009).

Positive responses of pulses crops to $\mathrm{B}$ application ( 0.5 to $2.5 \mathrm{~kg} \mathrm{~B}$ ha-1) have been largely reported from Bihar, Orissa, West Bengal, Assam, and Punjab (Takkar et al., 1997). The genotypes of a crop either susceptible or tolerant to B helps in determining the rate and method of boron application to enhance the crop yield (Ceyhan and Onder, 2007). Interaction of B with other nutrients may take place in soils and/or in plants. Interactions may lead to the increased availability (synergistic) or adversely affect the availability (antagonistic) of those nutrients (Sakal et al., 1988). Temperature as an abiotic factor plays an important role. At chilling temperature, B uptake, transport and partitioning into growing shoots are strongly impaired, and B use efficiency in the growing tissues is reduced (Ye, 2004). Hence, boron plays an important role in growth and development of higher plants, especially, horticulture crops, crucifers and legumes.

\section{Response of legume crops to boron application}

It has been observed that deficiency of boron drastically reduces nodulation, growth and yield of legumes due to insufficient supply of carbohydrates to bacteria in the root nodules and inadequate conversion of starch to soluble sugars (Brenchley and Thornton, 1925; Walter et al., 1982; Tripathy et al., 1999).

Application of $1 \mathrm{~kg} \mathrm{~B} \mathrm{ha}{ }^{-1}$ has been reported to produce an additional pod yield of $7.38 \mathrm{q}$ ha $^{-1}$ in French bean (Singh and Singh, 1990), but its application above this level proved to be detrimental while in coarse textured highly calcareous soils, application of 2.0 and $2.5 \mathrm{~kg}$ $\mathrm{B} \mathrm{ha}{ }^{-1}$ resulted in an increase in grain yield of black gram and chickpea by 33 and 38 per cent, respectively (Sakal et al., 1988). A reduction in seed yield of black gram up to 40-50 per cent as a result of boron deficiency in soils with hot water soluble boron content (HWS-B) of $0.12-0.14 \mathrm{mg} \mathrm{B} \mathrm{kg}^{-1}$ has also been reported (Rerkasem et al., 1988). Similarly, in boron deficient soils of Thailand a reduction in yield of black gram has been reported upto 70 per cent and while in green gram by 21 per cent (Rerkasem, 1991).

The grain yield of green gram was found to be significantly increased by application of boron, however, early growth of the crop in soils on low boron contents is depressed because of the large percentage of abnormal seedling but increasing boron content of the soil to $0.36 \mathrm{mg} \mathrm{B} \mathrm{kg}^{-1}$ eliminates any such abnormal seedlings regardless of the seed boron content (Rerkasem et al., 1990). In black gram, symptoms of boron deficiency were observed as chlorosis of leaf margins, inhibited floral development, brittleness, shortened internodes and reduced pod set which were similar to those as reported in black bean (Howeler et al., 1978). The symptoms were corrected by an application of $4 \mathrm{~kg}$ borax $\mathrm{ha}^{-1}$. In addition, the boron application also increased pod set and seed yield. Boron application increased dry matter yield and concentration of $\mathrm{B}$ in white clover and lucerne grown on silty loam soils of New Zealand with $\mathrm{pH} 5.9$ and available boron content 0.28 ppm (Sherrell, 1983a; Sherrell, 1983b).

Dear and Lipsett (1987) reported in cerealclover rotation, herbage yields of subterranean clover increased by 25 per cent with application B but seed yield increased 21-fold with B application. Increasing levels 
of boron increased dry matter yield of berseem up to $2 \mathrm{ppm}$. Thereafter, yield decreased with higher doses of boron application (Pal et al., 1989). Prakash and Dey (1997) reported that black gram sprayed with $0,0.01$ per cent, 0.02 per cent or 0.03 per cent B solutions (as borax) had a positive effect on crop in field trials in kharif season. Ceyhan and Onder (2007) studied the effect of boron on yield and yield components of five chickpea (Cicerarietinum) genotypes, namely Akc, in-91, Population, Go"kc,e, I'zmir-92, and Menemen-92 in calcareous soils in central Anatolian Turkey. They observed that grain yields in all genotypes (except for Go"kc.e) were significantly increased by $1 \mathrm{~kg} \mathrm{ha}^{-1} \mathrm{~B}$ application. Genotypes studied showed significant variations with respect to their responses to additional B. Dixit and Elamathi (2007) reported that foliar application of boron $(0.2$ per cent) in green gram increased the plant height, number of nodules plant ${ }^{-1}$, dry weight plant $^{-1}$ and number of pods plant ${ }^{-1}, 1000$-seed weight, grain yield and haulm yield over the control. Harmankaya et al., (2008) observed that the yield loss in common bean (Phaseolus vulgaris L.) was due to boron deficiency when the susceptible cultivars were grown in calcareous boron deficient soils. The yield was obtained higher in boron applied genotypes (Sehirali-90, Yunus-90, Karacasehir-90, Onceler-90, Goyniik-98 and Akman-98) than control. Applications of soil and foliar boron increased yield average of 10 and 20 per cent, respectively. Kaisher et al., (2010) conducted a field experiment on mung bean in sandy loamy textured boron-deficient soil in Bangladesh. They observed that application of boron at the rate of $5 \mathrm{~kg} \mathrm{~B} \mathrm{ha}^{-1}$ had significant effect on plant height, number of branches plant ${ }^{-1}$, number of pods plant ${ }^{-1}$, number of seeds pod $^{-1}, 1000$-seed weight and seed yield of mung bean seed. Stoltz and Wallenhammar (2013) studied the effect of soil and foliar applied boron (B) on flower development, nectar production, seed yield and germination in organic red clover was investigated in B deficient soils. The results showed that there is a greater increase in seed yield when B is applied to the soil compared with foliar application. Among different treatments, soil applied $0.5 \mathrm{~kg} \mathrm{ha}^{-1}$ dose was reported optimum. Padbhushan and Kumar (2014) conducted a greenhouse experiment with green gram grown on boron (B) deficient calcareous soils was to study the influence of soil and foliar applied boron on green gram. The treatments comprised of four levels of soil applied boron viz. 0.5, 0.75, 1.0 and 1.5

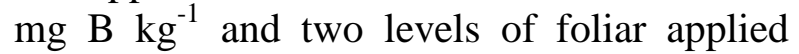
boron viz. 0.1 and 0.2 per cent borax solution with common control. It was found that soil applied boron has more influence on mean dry matter yield while foliar applied boron has on mean grain yield. Among all soil applied boron $0.5 \mathrm{mg} \mathrm{kg}^{-1}$ is best treatment while $0.1 \%$ is best foliar treatment. Soil applied boron was at the par with foliar applied boron. Khurana et al., (2012) in a field study reported that berseem fodder yield increased significantly in the first and second cuttings with soil application of $0.75 \mathrm{~kg} \mathrm{~B} \mathrm{ha}{ }^{-}$ ${ }^{1}$. However, significant increase in yield was obtained in the third cutting with the application of $1.0 \mathrm{~kg} \mathrm{~B} \mathrm{ha}{ }^{-1}$. Sakal et al., (1999) evaluated the direct and residual effect of varying levels of $\mathrm{B}$ on maize-lentil cropping system through a field experiment on calcareous soils. It was revealed that increasing levels of B application significantly increased the yield of maize and lentil up to $16 \mathrm{~kg}$ borax $\mathrm{ha}^{-1}$. Lentil was found to be more responsive to $\mathrm{B}$.

\section{Responses of oilseed crops to boron application}

Application of boron markedly increased kernel yield and quality of groundnut (Harris and Gilman, 1957; Harris and Brolman, 1966). However, it was observed that $1.1 \mathrm{~kg}$ 
$\mathrm{B} \mathrm{ha} \mathrm{h}^{-1}$ in linseed showed a non-significant increase in grain yield by $0.67-0.74 \mathrm{q} \mathrm{ha}^{-1}$ over control (Chourasia et al., 1992). Sinha et al., (1991) studied the effect of boron application on yield of various kharif and rabi crops and found the increase in the yield of all the crops. The maximum response was observed in onion and minimum in lentil crop. The crops like groundnut, maize and onion, $2.5 \mathrm{~kg} \mathrm{~B} \mathrm{ha}^{-1}$ was found to produce the highest yield but for crops such as sweet potato, Sunflower, mustard and lentil, application of only $1.5 \mathrm{~kg} \mathrm{~B} \mathrm{ha}^{-1}$ proved to be beneficial. Malewar et al., (2001) reported that with increasing levels of borax up to 10 $\mathrm{kg}$ Borax $\mathrm{ha}^{-1}$, stover yield increased from 9.47 to 14.41 per cent and seed yield increased from 6.54 to 10.21 per cent in mustard. Sarker et al., (2002) observed a significant variation in respect of yield components of soybean on a silt loam soil at different levels of boron. They reported that boron at the rate of $4.0 \mathrm{~kg} \mathrm{ha}^{-1}$ produced highest plant height and branches per plant. Boron application at the rate of $1.0 \mathrm{~kg} \mathrm{ha}^{-1}$ increased effective pod per plant while boron at the rate of $2.0 \mathrm{~kg} \mathrm{~B} \mathrm{ha}^{-1}$ produced higher 100 seed weight significantly. Similarly, Ross et al., (2006) found that there was increase in the number of plant nodes and plant height in soybean crop with increasing levels of boron up to $1.12 \mathrm{~kg} \mathrm{~B} \mathrm{ha-1}$, however, significant increase was observed up to $0.56 \mathrm{~kg} \mathrm{~B} \mathrm{ha}^{-1}$ of application.

Hemantaranjan et al., (2000) observed that foliar application of boron as boric acid at the rate of $50 \mathrm{mg} \mathrm{kg}^{-1}$ and $100 \mathrm{mg} \mathrm{kg}^{-1}$ boron on soybean increased morpho-physiological attributes, total dry matter production and seed yield. Hossain et al., (2012) conducted a field experiment to evaluate the response of different varieties of $B$. napus, $B$. campestrisand $B$. juncea to boron application. Boron application was made at 0 and $1 \mathrm{~kg} / \mathrm{ha}$. The response of the three Brassica species followed the order: $B$. napus $>B$. campestris $>B$. juncea. It was recommended that different varieties of musturd can grow in the moderately $\mathrm{B}$ deficient soils with a minimum dose $\left(0.5 \mathrm{~kg} \mathrm{ha}^{-1}\right)$ of B application. In Egypt, Sesame plants were sprayed with different concentrations of boron solution at 20, 30 and $40 \mathrm{ppm}$ at different stages of plant growth (1, 2 and 3 months). Treating plants with boron solution at $20 \mathrm{ppm}$ gave the highest results in growth criteria as compared with corresponding control or plants treated with higher boron solutions (30 and $40 \mathrm{ppm}$ ). The highest oil viscosity was recorded at a boron concentration of $30 \mathrm{ppm}$ (Hamideldin and Hussein, 2014).

Prevention and/or correction of B deficiency in crops on B-deficient soils can have a dramatic effect on yield and produce quality of pulse and legume crops. An increase in yield of 33\% in black gram, 38\% in Chick pea, $25 \%$ in clover, $20 \%$ in common bean, and $10.21 \%$ in mustard was observed with B fertilization. Both soil and foliar application methods of B are effective in improving crop yield.

\section{Acknowledgements}

Author would like to thank Dr. V. K. Phogat, Professor, Department of Soil Science, CCSHAU, Hisar, for valuable suggestions.

\section{References}

Anantawiroon, P., Subedi, K. D., and Rerkasem, B.1997. Screening wheat for boron efficiency In: boron in soils and Plants (Eds.) R. W. Bell and B. Rerkasem. Kluwer Academic Publishers, Dordrecht, Pp. 101-104.

Bansal, R. L., Nayyar, V. K., and Brar J. S.2003. Available B status of soils in central plain region of Punjab. Journal of Research Punjab Agricultural. 40: 
172-176.

Brenchley, W. W., and Thornton, H. G. 1925. The relation between the development structure and functioning of the nodules of the Viciafaba, as influenced by the presence or absence of boron in the nutrient medium. Proceedings of the Royal Society of London. Series B, Biological sciences. 98: 373-398.

Ceyhan, E., and Onder, M.2007. Response of chickpea cultivars to application of boron in boron- deficient calcareous soils. Communications in Soil Science Plant Analysis. 38: 2381-2399.

Chourasia, S. K., Namdeo, K. N., and Chaurasia, S. C. 1992. Effect of nitrogen, Sulphur and boron on growth, yield and quality of linseed (Linum usitatissimum). Indian Journal of Agronomy. 37: 496-499.

Dear, B. S., and Lipsett, J. 1987. The effect of boron supply on the growth and seed production of subterranean clover (Trifolium subterraneum). Australian Journal of Agricultural Research. 38:537-546.

Dixit, P. M., and Elamathi, S. 2007. Effect of foliar application of DAP, micronutrients and NAA on growth and yield of green gram (Vigna radiata L.). Legume Research. 30: 305-307.

Hamideldin, N., and Hussein, O. S. 2014. Response of Sesame (Sesamum indicum L.) Plants to Foliar Spray with Different Concentrations of Boron. Journal of the American Oil Chemists Society. 91:1949-1953.

Harmankaya, M., Onder, M., Hamurcu, M., Ceyhan, E., and Gezgin, S. 2008. Response of common bea (Phaseolus vulgaris L.) cultivars to foliar and soil applied boron in boron deficient calcareous soils. African Journal Biotechnology. 7: 3275-3282.
Harris, H. C., and Brolman, J. B. 1966. Effect of imbalance of boron on peanuts. Agronomy Journal. 58: 97-98.

Harris, H. C., and Gilman, R. L. 1957. The effect of boron on peanuts. Soil Science. 84: 233-242.

Hemantaranjan, A., Trivedi, A. K., and Maniram. 2000. Effect of foliar applied boron and soil applied iron and Sulphur on growth and yield of soybean (Glycine max L. MERR). Indian Journal Plant Physiology. 5: 142-144.

Hossain M. A., Jahiruddin M., and Khatun, F. 2012. Response of mustard (brassica) varieties to boron application. Bangladesh Journal of Agricultural Research. 37(1): 137-148

Howeler, P., Flor, C. A., and Gonzalez, C. A. 1978. Diagnosis and correlation of $\mathrm{B}$ deficiency in beans and mungbeans in Mollisol from the Cauca Valley of Columbia. Agronomy Journal. 70:493497.

Kaisher, M. S., Rahman, M. A., Amin, M. H. A., Amanullah, A. S. M., and Ahsanullah, A. S. M. 2010. Effects of sulphur and boron on the seed yield and protein content of mungbean. Bangladesh Research Publications Journal. 3: 1181-1186.

Kanwar, J. S., and Randhawa, N. S.1974. Micronutrient research in soils and plants in India: A review. ICAR. Technical Bulletin (Agric). 50:1-60.

Khurana, M. P. S., Sadana, U. S., Manchanda, J. S., and Dhaliwal, S. S. 2012. Response of berseem (Trifolium alexandrium) to boron application in alluvium derived soil. Journal of Research Punjab Agricultural University. 49:223-226.

Malewar, G. U., Kate, S. D., Waikar, S. L., and Ismail, S. 2001. Interaction effects of zinc and boron on yield, nutrient uptake and quality of mustard (Brassica juncea L.) on a typihaplustert. Journal 
of Indian Society of Soil Science. 49:763-765.

Padbhushan, R., and Kumar D. 2014. Influence of Soil and Foliar Applied Boron on Green Gram in Calcareous Soils. International Journal of Agriculture, Environment and Biotechnology. 7(1): 129-136

Pal, B., Jadaun, S. P. S., and Raghav, C. S. 1989. Effect of phosphorus and boron application on dry matter yield and nutrient contents in berseem. Journal of the Indian Society of Soil Science. 37: 579-581.

Prakash, K., and Dey, S. C. 1997. Physiological efficiency and yield performance of some black gram (Vigna mungo L.) varieties as influenced by foliar application of boron. Plant Physiology and Biochemistry. 24: 2225.

Ranade, S. S., 2009. Role of micronutrients in integrated nutrient management-current trends and prospects. Instiute of Micronutrient Technology, Pune.

Rerkasem B (1991) Comparison of green gram (Vigna radiata $\mathrm{L}$.) and black gram (Vigna mungo L.) in boron deficiency. Proceedinds of the Mungbean Meeting. 90: 167-174.

Rerkasem B, Netsangtip R, Bell R W, Loneragan J F and Hiranburana $\mathrm{N}$ (1988) Comparative species responses to boron on a Typic Tropaqualf in Northern Thailand. Plant and Soil. 106: $15-21$.

Rerkasem, B., Bell, R. W., and Loneragan, J. F. 1990. Effects of seed and soil boron on early seedling growth of black and green gram $(V$. mungo and $V$. radiata) In: Plant Nutrition: Physiology and Applications (Ed.) M. L. Beusichem. Kluwer Academic Publishers, Dordrecht. Pp. 281-285.

Ross, J. R., Slaton, N. A., Brye, K. R., and DeLong, R. E. 2006. Boron fertilization influences on soybean yield and leaf and seed boron concentrations. Agronomy Journal. 98: 198-205.

Sakal, R., and Singh, A. P.1995. Boron research and agricultural production In: micronutrients research and agricultural production (Ed.) H. L. S. Tandon. Fertilizer and Consultation Organization, New Delhi, Pp.1-31

Sakal, R., Sinha, R. B., Singh, A. P., and Bhogal, N. S.1999. Effect of boron and FYM alone and in combination on boron nutrition of crops in maize-lentil cropping systems. Fertilizer News. 36: 43-49.

Sakal, R., Sinha, R. B., Singh, A. P.1988. Effect of B application on Black gram and Chickpea, Production in Calcareous soil. Fertilizer News. 33: 27-30.

Sarker, S. K., Chowdhury, M. A. H., and Zakir, H. M. 2002. Sulphur and boron fertilization on yield quality and nutrient uptake by Bangladesh soybean4. Journal of Biological Sciences. 2:729-733.

Sherrell, C. G. 1983a. Boron deficiency and response in white and red clovers and lucerene. New Zealand Journal of Agricultural Research. 26: 197-203.

Sherrell, C. G. 1983b. Effect of boron application on seed production of New Zealand herbage legumes. New Zealand Journal of Experimental Agriculture. 11: 113-117.

Shorrocks, V. M. 1997. The occurrence and correction of boron deficiency. Plant and Soil. 193: 121-148.

Singh, B. P., and Singh, B. 1990. Response of French bean to phosphorus and boron in acid alfisols in Meghalaya. Journal of the Indian Society of Soil Science. 38: 769-771.

Singh, M. V., 2008. Micronutrient Deficiencies in Crops and Soils in India In: Micronutrient deficiencies in Global Crop Production (Ed.) B. J. Alloway. 
Springer, Netherlands, Pp. 93-125.

Singh, S. P., and Nayyar, V. K.1999. Available B status of some alluvium derived arid and semi-arid soils of Punjab. Journal of the Indian Society of Soil Science. 47:801-02.

Sinha, R. B., Sakai, R., and Bhogal, N. S. 1991. Response of some field crops to B applications in calcareous soils. Journal of the Indian Society of Soil Science. 39:118-122.

Stoltz, E., and Wallenhammar, A. C. 2013. Influence of boron in organic red clover (Trifolium pratense L.) seed production. Grass and Forage Science. 69: 285-293.

Takkar P N, Singh M V and Ganeshamurthy A N (1997) A critical review of plant nutrient supply needs, efficiency and policy issue for Indian agriculture for the year 2000 In: Proceedings of a Seminar on Plant nutrient needs, supply, efficiency and policy issues:
2000-2025 (Eds.) J. S. Kanwar and J. C. Katyal, National Academy of Agricultural Sciences, New Delhi. Pp. 238-265

Tripathy, S. K., Patra, A. K., and Samui, S. C. 1999. Effect of micronutrient on nodulation, growth, yield and nutrient uptake by groundnut (Arachis hypogaea). Indian Journal of Plant Physiology. 4: 207-209.

Walter, J., Steigemann, W., Singh, T. P., Bartunik, H., Bode, W., and Huber, R. 1982. On the disordered activation domain in trypsinogen: chemical labeling and low-temperature crystallography. Acta Crystallographica Section B. 38: 1462-1472.

Ye, Z. 2004. Effect of low temperature on boron nutrition of Oilseed rape and sunflower, Perth, Western Australia. Ph.D. thesis, Murdoch University, Perth, Western Australia.

\section{How to cite this article:}

Sunil Kumar, Mamta Phogat and Manohar Lal. 2018. Response of Pulse and Oilseed Crops to Boron Application: A Review. Int.J.Curr.Microbiol.App.Sci. 7(03): 669-675. doi: https://doi.org/10.20546/ijcmas.2018.703.078 